\title{
PENGARUH MODEL PEMBELAJARAN PAIR CHECK BERBASIS PENILAIAN KINERJA TERHADAP KOMPETENSI PENGETAHUAN PKN SISWA KELAS IV
}

\author{
Ni Putu Arni Rahayuni ${ }^{1}$, I G A Agung Sri Asri ${ }^{2}$, Ni Wayan Suniasih ${ }^{3}$ \\ 1,2,3 Jurusan PGSD \\ Universitas Pendidikan Ganesha \\ Singaraja, Indonesia \\ email: arnirahayuni91@gmail.com \\ niwayan.suniasih@undiksha.ac.id ${ }^{3}$.
}

\begin{abstract}
Abstrak
Penelitian ini bertujuan untuk mengetahui pengaruh model pembelajaran Pair Check berbasis penilaian kinerja terhadap kompetensi pengetahuan PKn siswa kelas IV SDN Gugus Pattimura Denpasar Selatan tahun pelajaran 2017/2018. Desain penelitian ini adalah Penelitian Eksperimen semu dengan rancangan nonequivalent control group design. Populasi dalam penelitian ini adalah seluruh siswa kelas IV SDN Gugus Pattimura Denpasar Selatan yang berjumlah 301 siswa. Penentuan sampel dilakukan dengan teknik random sampling. Sampel yang didapatkan disetarakan terlebih dahulu menggunakan teknik matching. Penentuan kelompok eksperimen dan kelompok kontrol dilakukan dengan cara mengundi sehingga diperoleh siswa kelas IV SDN 1 Sesetan dengan jumlah 30 siswa sebagai kelompok eksperimen dan siswa kelas IV SDN 18 Sesetan dengan jumlah 30 siswa sebagai kelompok kontrol. Pengumpulan data dilakukan dengan menggunakan metode tes dalam bentuk tes objektif pilihan ganda biasa yang berjumlah 31 butir tes yang telah di validasi. Data kompetensi pengetahuan PKn dianalisis dengan menggunakan uji-t. Hasil analisis data diperoleh $\mathrm{t}_{\text {hitung }}=3,870$ sedangkan pada taraf signifikansi $5 \%$ dan $\mathrm{dk}=58$ diperoleh nilai $\mathrm{t}_{\text {tabel }}$ $=2,000$ sehingga $t_{\text {hitung }}=3,870>t_{\text {tabel }}=2,000$. Hasil analisis menunjukkan bahwa terdapat pengaruh model pembelajaran Pair Check berbasis penilaian kinerja terhadap terhadap kompetensi pengetahuan PKn siswa kelas IV SDN Gugus Pattimura Denpasar Selatan tahun pelajaran 2017/2018.
\end{abstract}

Kata kunci : Pair Check, penilaian kinerja, kompetensi pengetahuan PKn

\begin{abstract}
This study was aimed to determine the effect of pair check learning model assisted by performance assessment on civic education competence of the fourth-grade students of SDN Gugus Pattimura South Denpasar in the academic year 2017/2018. This type of research was a quasi-experiment using a group design of nonequivalent control group design. The population of this research was all of the student in the fourth-grade of the elemtary school in Pattimura District of South Denpasar containing 301 students. The sample was determined by random sampling technique by randomizing the class. The sample obtained are equalized first using the matching technique. The determination of the experimental group and the control group was conducted by drawing to be obtained the fourth-grade students of SDN 1 Sesetan with the total of 30 students as the experimental group and the fourth-grade students of SDN 18 Sesetan with the total of 30 students as the control group. The knowledge competence data of civic education subject were collected by using the instrument in the form of objective test or multiple choice. The test that consisted of 31 items has been validated. The knowledge competence of civic education subject was analyzed using T-test. The data were proven by the result of $t_{\text {count }}=3,870>t_{\text {table }}(a=0,05,58)=2,000$ so $t_{\text {count }}=3,870>t_{\text {table }}=$ 2,000 . Thus, it can be concluded that learning model of pair check assisted by performance assesment affects students competence of civic education subject of the foruth-grade in Gugus Pattimura South Denpasar in the academic year 2017/2018.
\end{abstract}

Keywords: Pair check, performance assesment, civic education competence. 


\section{Pendahuluan}

Perkembangan teknologi dan ilmu pengetahuan menuntut adanya berbagai peningkatan dan perubahan-perubahan pendidikan guna memberi kemudahan bagi peserta didik untuk mengikuti kemajuan teknologi dan ilmu pengetahuan. "Pendidikan adalah suatu proses dalam rangka mempengaruhi peserta didik supaya mampu menyesuaikan diri sebaik mungkin dengan lingkungannya dan dengan demikian akan menimbulkan perubahan" (Hamalik, 2012:3). Dan menurut Mulyasa (2006:15) "pendidikan merupakan wahana untuk meningkatkan dan mengembangkan kualitas sumber daya manusia". Berdasarkan uraian tersebut jadi dapat disimpulkan bahwa pendidikan adalah suatu proses yang terencanadalam perwujudan kebudayaan yang dapat mempengaruhi manusia untuk dapat menyesuaikan diri dan untuk mengembangkan potensi diri.

Seiring dengan perkembangan jaman, maka secara otomatis pola pikir masyarakat berkembang dalam setiap aspek. Hal yang sangat berpengaruh terutama dalam dunia pendidikan yang menuntut adanya inovasi baru yang dapat membuat perubahan yang berbeda dari sebelumnya yakni kurikulum. "Kurikulum 2013 dirancang untuk memberikan pengalaman belajar seluas-luasnya bagi siswa dalam mengembangkan kemampuan untuk bersikap, berpengetahuan, berketerampilan, dan bertindak" (Kosasih, 2014:12). Pada Permendikbud No 57 Tahun 2014 dinyatakan bahwa Kurikulum pada Sekolah Dasar/ Madrasah Ibtidayah yang telah dilaksanakan sejak tahun ajaran 2013/2014 disebut kurikulum 2013 Sekolah Dasar/ Madrasah Ibtidayah. Jadi berdasarkan pemaparan diatas dapat disimpulkan bahwa kurikulum merupakan sejumlah mata pelajaran yang harus ditempuh oleh siswa untuk mendapatkan pengalaman belajar seluas-luasnya yang pada saat ini disebut kurikulum 2013.

Pada saat ini pembelajaran di sekolah dasar dilaksanakan melalui pembelajaran tematik terpadu, yaitu pembelajaran terdiri dari tema-tema tertentu yang di dalamnya terdapat beberapa mata pelajaran yang saling berkaitan. Pembelajaran tematik dengan materi PKn di sekolah dasar diartikan sebagai suatu proses belajar mengajar dengan tujuan membantu peserta didik agar dapat belajar dengan baik dan membentuk manusia Indonesia seutuhnya dalam pembentukan karakter bangsa yang diharapkan mengarah pada penciptaan suatu masyarakat yang menempatkan demokrasi dalamkehidupan berbangsa dan bernegara yang berlandaskan pada Pancasila, UUD, dan norma-norma yang berlaku di masyarakat yang diselenggarakan selama enam tahun (Susanto, 2014).

Berdasarkan hasil observasi di sekolah dasar Gugus Pattimura proses pembelajaran di dalam kelas belum menerapkan model pembelajaran yang baru. Selain itu interaksi antar siswa dengan siswa lainnya masih belum terlihat, dan interaksi tersebut lebih mengarah kepada hal yang dapat mempengaruhi proses pembelajaran seperti siswa asik berbicara dengan siswa lainnya sehingga tidak mendengarkan penjelasan guru. Hal itu menyebabkan kompetensi pengetahuan PKn yang dimiliki siswa cenderung rendah, karena semangat dan motivasi siswa tidak tampak saat menerima pelajaran. Untuk dapat mencapai hal yang maksimal kompetensi pengetahuan PKn maka dengan memberikan inovasi dalam pembelajaran, proses pembelajaran akan berjalan lebih menyenangkan dan bermakna sehingga kompetensi pengetahuan PKn menjadi lebih maksimal.

Pendidikan kewarganegaraan atau PKn penting diberikan sejak usia sekolah dasar untuk mempersiapkan peserta didik menjadi insan yang terampil, cerdas, berprilaku yang baik, dan sadar akan hak dan kewajibannya sebagai warga negara. Melalui mata pelajaran PKn di sekolah dasar siswa diharapkan dapat memiliki pengetahuan dan wawasan tentang pendidikan politik demokrasi, memiliki kepekaan dan kesadaran terhadap masalah sosial di lingkungannya (Fathurohman dan Wuryandani 2011). Berdasarkan pemaparan diatas PKn adalah pendidikan yang memfokuskan pada pembentukan kepribadian peserta didik sejak dini agar mampu membentuk sikap dan mental yang baik dan demokratis. Penguasaan konsep-konsep pengetahuan, terutama konsep materi PKn sulit dipahami oleh siswa, hal tersebut dapat disebabkan oleh dua faktor yakni faktor internal dan faktor eksternal. Faktor 
internal tersebut dapat disebabkan karena guru belum pernah menggunakan model pembelajaran yang inovatif dalam proses pembelajaran. Banyak hal yang dapat dilakukan untuk memberikan inovasi baru dalam proses pembelajaran. Salah satu inovasi pembelajaran yang dapat dilakukan adalah menerapkan model pembelajaran yang bervariasi pada setiap pembelajaran. Model pembelajaran memiliki berbagai macam jenis, antara lain model pembelajaran kontekstual, model pembelajaran kooperatif, model pembelajaran berbasis masalah, dan lain sebagainya.

Untuk menjadikan siswa cerdas, terampil, dan berkarakter dapat diujicobakan dengan memberikan inovasi pembelajaran yang dapat mengoptimalkan kompetensi pengetahuan PKn siswa dan untuk meningkatkan interaksi antara guru dengan siswa dan siswa dengan siswa sehingga pembelajaran PKn lebih bermakna dan materi tidak cepat dilupakan oleh siswa, dengan menerapkan Model Pembelajaran Pair Check berbasis penilaian kinerja. Menurut Huda (2016:211) "model pembelajaran ini menerapkan pembelajaran kooperatif yang menuntut kemandirian dan kemampuan siswa dalam menyelesaikan persoalan". Kemandirian dalam proses pembelajaran yang dimaksud yakni siswa mampu menyelesaikan sebuah persoalan dengan usahanya sendiri. Model Pair Check (pasangan mengecek) merupakan model pembelajaran dimana siswa saling berpasangan dan menyelesaikan persoalan yang diberikan. Model ini bertujuan untuk meningkatkan kemampuan siswa dalam menuangkan ide, pikiran, pengalaman, dan pendapatnya dengan benar (Shoimin, 2014). Berdasarkan beberapa pendapat para ahli tersebut, dapat disimpulkan bahwa model pembelajaran Pair Check merupakan model pembelajaran secara berkelompok yang mendorong siswa untuk melatih rasa sosial siswa, dan lebih mengutamakan kepentingan kelompok dibandingkan kepentingan pribadi.

Dalam kegiatan belajar tersebut guru dapat mengetahui karakteristik dan kemampuan dari masing-masing peserta didik dengan penilaian kinerja. Penilaian kinerja tersebut dapat dilakukan guru melalui pengamatan secara langsung saat siswa melakukan sesuatu dengan kriteria yang telah ditetapkan oleh guru sebelumnya. Kunandar (2014) menyatakan bahwa penilaian kinerja adalah penilaian tindakan atau tes praktik yang secara efektif dapat digunakan untuk kepentingan pengumpulan berbagai informasi tentang bentukbentuk perilaku atau keterampilan yang diharapkan dari peserta didik dan dilakukan dengan cara mengamati peserta didik dalam melakukan sesuatu secara langsung. "Peserta didik berbicara dalam diskusi pun termasuk unjuk kerja. Apalagi ketika sedang berlatih berpidato atau bermain drama" (Arikunto, 2015:244). Jadi berdasarkan pemaparan diatas dapat disimpulkan bahwa penilaian kinerja merupakan suatu penilaian yang dilakukan oleh guru melalui kegiatan mengamati kegiatan yang dilakukan oleh peserta didik. Kegiatan yang dapat dinilai dalam penilaian kinerja meliputi kegiatan praktik, berbicara, berdiskusi, kemampuan memecahkan masalah, dan kegiatan lainnya.

Dilihat dari hasil penelitian yang dilakukan oleh (1) Yantiani (2013) menunjukkan terdapat perbedaan yang signifikan hasil belajar siswa yang mengikuti model pembelajaran kooperatif tipe pair check dengan siswa yang mengikuti pembelajaran konvensional; (2) Penelitian yang dilakukan oleh Widiadnyani (2014) menunjukkan terdapat perbedaan yang signifikan terhadap hasil belajar PKN antara siswa yang dibelajarkan dengan model pembelajaran Pair Cheks berbatuan media lingkungan hidup dengan siswa yang dibelajarkan dengan pembelajaran konvensional. Berdasarkan pemaparan tersebut, maka dilakukan penelitian yang berjudul Pengaruh Model Pembelajaran Pair Check Berbasis Penilaian Kinerja Terhadap Kompetensi Pengetahuan PKn Siswa Kelas IV SDN Gugus Pattimura Denpasar Selatan Tahun Pelajaran 2017/2018.

\section{Metode}

Penelitian ini dilaksanakan di Gugus Pattimura Kecamatan Denpasar Selatan Tahun Pelajaran 2017/2018. Adapun waktu penelitian ini dilaksanakan pada bulan Maret sampai dengan bulan April 2018. Perlakuan diberikan sebanyak 6 kali di kelompok eksperimen dan terkait dengan kelompok kontrol di berikan materi yang sama dengan kelompok eksperimen. 
Jenis penelitian yang dilakukan dalam penelitian ini adalah penelitian eksperimen. Desain eksperimen yang digunakan dalam penelitian ini adalah desain eksperimen semu (Quasi Eksperiment). Bentuk desain eksperimen semu yang digunakan dalam penelitian ini adalah "nonequivalent control group design". Pada desain ini baik kelompok eksperimen maupun kelompok kontrol dibandingkan. Pre-test diberikan untuk kelompok kontrol dan kelompok eksperimen. Setelah itu peneliti memberikan perlakuan, yaitu dengan memberikan materi dengan menggunakan model pembelajaran pair check berbasis penilaian kinerja kepada kelompok eksperimen dan memberikan materi yang sama terkait kurikulum 2013 kepada kelompok kontrol. Kemudian setelah memberi perlakuan, dilakukan post-test untuk mengetahui hasil kompetensi pengetahuan PKn.

Agung (2014:69) menyatakan bahwa, "Populasi merupakan keseluruhan dari objek dalam suatu penelitian." Hal serupa juga disampaikan Sugiyono (2016:117) "populasi merupakan wilayah generalisasi yang terdiri dari objek/subjek yang mempunyai kualitas dan karakteristik tertentu yang ditetapkan oleh peneliti untuk dipelajarari dan ditarik kesimpulannya." Populasi dalam penelitian ini hanya sekolah dasar negeri di gugus Pattimura yaitu seluruh siswa kelas IV di SDN Gugus Pattimura Kecamatan Denpasar Selatan tahun pelajaran 2017/2018.

Pada penelitian ini sampel yang digunakan untuk penelitian adalah bagian dari populasi penelitian. Sampel adalah perwakilan atau bagian dari populasi yang mewakili seluruh anggota populasi untuk dijadikan sebagai sumber data dalam suatu penelitian. Dalam penelitian ini sampel terdiri atas dua kelas, yaitu satu kelas eksperimen dan satu kelas kontrol. Teknik yang digunakan dalam pengambilan sampel ini disebut sebagai teknik random sampling. Kelas dipilih sebagaimana telah terbentuk tanpa campur tangan peneliti dan tidak dilakukan pengacakan individu, kemungkinan pengaruh-pengaruh dari keadaan subjek mengetahui dirinya dilibatkan dalam eksperimen dapat dikurangi sehingga penelitian ini benar-benar menggambarkan pengaruh perlakuan yang diberikan. Untuk mendapatkan kelas yang setara dari segi akademik, maka teknik yang digunakan dalam penyetaraan kelompok adalah teknik matching. Darmadi (2014) menyatakan matching adalah suatu teknik yang digunakan untuk menyeragamkan kelompok pada suatu variabel atau lebih yang oleh peneliti telah diidentifikasi mempunyai hubungan yang erat dengan penampilan (performance) variabel tidak bebas. Satu anggota dipilih secara random kemudian dicari jodohnya. Untuk masing-masing subjek yang ada pada kelompok eksperimen dipasangkan dengan subjek lain yang sama atau nilainya mirip pada kelompok kontrol. Sedangkan jika ada subjek yang tidak mendapat pasangan maka harus dihilangkan dalam penelitian namun tetap diikutkan dalam proses pemberian perlakuan saat penelitian. Setelah melakukan pengundian maka di dapat 2 kelas yakni kelas IV SDN 1 Sesetan dan kelas IV SDN 18 Sesetan. Kelas IV SDN 1 Sesetan berjumlah 30 orang dan kelas IV SDN 18 Sesetan berjumlah 42 orang. Nilai pretest kedua kelompok disetarakan menggunakan teknik matching dan mendapat 30 pasang siswa yang memiliki kemampuan setara secara akademik. Penyetaraan kelompok selengkapnya terlampir pada lampiran 15 halaman 93.

Berdasarkan hasil tersebut, sampel dalam penelitian ini masing-masing kelas berjumlah 30 siswa. Setelah diketahui kedua kelompok setara, maka dilakukan pengundian lagi untuk menentukan kelas eksperimen dan kelas kontrol. Berdasarkan hasil undian, diperoleh kelas IV SDN 1 Sesetan sebagai kelas eksperimen, dan kelas IV SDN 18 Sesetan sebagai kelas kontrol.

Langkah-langkah yang ditempuh dalam penelitian ini adalah 1) menentukan populasi penelitian, 2) menentukan sampel penelitian dengan teknik random sampling, 3) menyusun RPP (Rencana Pelaksanaan Pembelajaran), dengan model pembelajaran Pair Check berbasis penilaian kinerja, 4) mengkonsultasikan instrumen penelitian pretest dan posttest kepada wali kelas IV dan dosen pembimbing, 5) mengkonsultasikan RPP kepada wali kelas dan dosen pembimbing, 6) Mengadakan uji coba instrumen penelitian soal posttest, 7) memberikan pretest kepada 2 kelompok dari seluruh populasi yang telah diundi untuk membuktikan kesetaraan kelompok, 8) Untuk kesetaraan kelompok menganalisis data pretest kepada 2 kelompok populasi yang telah diundi dengan teknik matching, 9) 
melakukan pengundian kembali dalam menentukan kelompok eksperimen dan kelompok kontrol, 10) Memberikan perlakuan (treatment) pada kelas eksperimen berupa model pembelajaran Pair Check berbasis penilaian kinerja, 11) Perlakuan diberikan sebanyak 6 kali di kelas eksperimen. Pada kelas kontrol tidak diberi perlakuan namun materi pembelajaran yang diberikan sama dengan kelas eksperimen, 11) Memberikan posttest pada akhir eksperimen, terhadap kelompok eksperimen dan kelompok kontrol, 12) melakukan analisis hasil penenlitian untuk menguji hipotesis yang diajukan.

Dalam penelitian ini, teknik analisis yang digunakan untuk menganalisis data Kompetensi Pengetahuan PKn adalah teknik analisis statistik inferensial. Analisis data pada penelitian ini menggunakan uji-t, sebelum dilakukan uji-t dilakukan uji prasyarat analisis. Uji normalitas dimaksudkan untuk mengetahui apakah sebaran data skor Kompetensi pengetahuan PKn siswa masing-masing kelompok berdistribusi normal atau tidak sehingga dapat menentukan teknik analisis datanya. Uji Normalitas sebaran data penelitian ini menggunakan Chi Kuadrat. Kriterian pengujian pada taraf signifikansi 5\% dan derajat kebebasannya $\mathrm{n}-1$, adalah jika harga $\mathrm{X}_{\text {hitung }} \leq \mathrm{X} 2_{\text {tabel }}$ maka $\mathrm{H}_{\mathrm{o}}$ diterima (gagal ditolak) dan $\mathrm{H}_{\mathrm{a}}$ ditolak yang berarti sebaran data berdistribusi normal, sedangkan jika harga $\mathrm{X} 2_{\text {hitung }}$ $>\mathrm{X} 2_{\text {tabel }}$ maka $\mathrm{H}_{\mathrm{o}}$ ditolak dan $\mathrm{H}_{\mathrm{a}}$ diterima (gagal ditolak) yang berarti data tidak berdistribusi normal. Uji kesamaan dua varians digunakan untuk menguji apakah sebaran data homogen atau tidak, yaitu dengan membandingkan variansnya. Uji homogentitas dapat dilakukan apabila kelompok data tersebut dalam distribusi normal. Untuk menguji homogenitas varians untuk kedua kelompok digunakan uji $\mathrm{F}$. Kriteria pengujian $\mathrm{H}_{0}$ diterima jika $\mathrm{F}_{\text {hitung }} \leq \mathrm{F}_{\text {tabel }}$ maka sampel homogen, Sebaliknya jika $F_{\text {hitung }}>F_{\text {tabel }}$ maka kedua kelompok data tidak homogen (heterogen). Data yang telah diuji normalitas dan homogenitasnya selanjutnya dilakukan uji hipotesis dengan menggunakan uji-t. Adapun hipotesis penelitian yang diuji yaitu $\mathrm{H}_{\circ}$ yaitu Tidak terdapat pengaruh model pembelajaran Pair Check berbasis penilaian kinerja terhadap kompetensi pengetahuan PKn siswa kelas IV SDN Gugus Pattimura Denpasar Selatan tahun pelajaran $2017 / 2018$. Kriteria pengujian pada taraf signifikansi $5 \%$ dengan dk $=\mathrm{n} 1+\mathrm{n} 2-2$, ini yaitu jika $\mathrm{t}_{\text {hitung }} \leq \mathrm{t}_{\text {tabel }}$ maka $\mathrm{H}_{\mathrm{o}}$ diterima dan $\mathrm{H}_{\mathrm{a}}$ ditolak, dan jika $\mathrm{t}_{\text {hitung }}>\mathrm{t}_{\text {tabel }}$ maka $\mathrm{H}_{0}$ ditolak dan $\mathrm{H}_{\mathrm{a}}$ diterima.

\section{Hasil dan Pembahasan}

Data pada penelitian ini diklasifikasikan menjadi dua yaitu, (1) Kompetensi Pengetahuan PKn siswa kelas IV yang dibelajarkan dengan Model Pembelajaran Pair Check Berbasis Penilaian Kinerja, (2) Kompetensi pengetahuan PKn siswa kelas IV yang dibelajarkan dengan pembelajaran santifik. Berikut adalah sajian data dari masing-masing kelompok tersebut. Deskripsi data kompetensi pengetahuan PKn siswa melalui tabel distribusi frekuensi meliputi rerata(mean) dan varians. Berdasarkan perhitungan tersebut diperoleh rerata kompetensi pengetahuan PKn kelompok eksperimen $\overline{X_{1}}=84,13$ serta berdasarka perhitungan diperoleh varians kompetensi pengetahuan PKn kelompok eksperimen $s_{1}{ }^{2}=75,49$. Sementara itu berdasarkan perhitungan diperoleh rerata kompetensi pengetahuan PKn kelompok kontrol $\overline{X_{2}}=76,13$ serta berdasarkan hasil perhitungan diperoleh varians kompetensi pengetahuan PKn kelompok kontrol $s_{2}{ }^{2}=52,67$.

Uji prasyarat dilakukan terlebih dahulu sebelum uji hipotesis menggunakan uji-t. Uji prasyarat tersebut meliputi uji normalitas dan uji homogenitas varians diuraikan berikut ini. Pengujian normalitas data dilakukan pada dua kelompok data, meliputi data kelompok eksperimen dan kelompok kontrol. Pada taraf signifikansi $5 \%$ dan $\mathrm{dk}(\mathrm{n}-1)$ diperoleh $\mathrm{X}_{\text {tabel }}^{2}=$ 11,07. Kriteria pengujian pada uji normalitas adalah jika $x^{2}{ }_{\text {hitung }}<x_{\text {tabel }}^{2}$ maka sebaran data kedua kelompok berdistribusi normal. Berdasarkan hasil uji normalitas data kompetensi pengetahuan PKn kelompok eksperimen diperoleh $X^{2}{ }_{\text {hitung }}=3,972$. Karena $X^{2}{ }_{\text {hitung }}=3,972<$ $\mathrm{X}_{\text {tabel }}^{2}=11,07$ sehingga $\mathrm{H}_{0}$ diterima yang berarti data kompetensi pengetahuan $\mathrm{PKn}$ kelompok eksperimen berdistribusi normal. Perhitungan selengkapnya terlampir pada lampiran 22 halaman 127. Semetara hasil uji normalitas kelompok kontrol menunjukkan 
bahwa $X^{2}$ hitung $=5,717$. Karena $X^{2}$ hitung $=5,717<X^{2}$ tabel $=11,07$. sehingga $H_{0}$ diterima yang berarti data kompetensi pengetahuan PKn kelompok kontrol berdistribusi normal.

Dari hasil analisis, diperoleh $F_{\text {hitung }}=1,43$ dan $F_{\text {tabel }}=1,85$. Hal ini berarti $F_{\text {hitung }}=$ $1,43<F_{\text {tabel }}=1,85$, sehingga data kedua kelompok memiliki varians yang homogen. Berdasarkan hasil uji prasyarat yang terdiri dari uji normalitas dan uji homogenitas varians, disimpulkan bahwa data kedua kelompok sampel ialah berdistribusi normal dan memiliki varians yang homogen. Dengan demikian, uji hipotesis menggunakan uji-t dapat dilakukan. Pengujian homogenitas varians antar kelompok dimaksudkan untuk meyakinkan bahwa perbedaan yang diperoleh uji-t benar - benar berasal dari perbedaan antar kelompok bukan disebabkan oleh perbedaan di dalam kelompok. Uji homogenitas varians yang dilakukan dalam penelitian ini menggunakan uji F dari Havley.

Hipotesis yang diuji adalah $\mathrm{H}_{0}$ yaitu Tidak terdapat pengaruh model pembelajaran Pair Check berbasis penilaian kinerja terhadap kompetensi pengetahuan PKn siswa kelas IV SDN Gugus Pattimura Denpasar Selatan tahun pelajaran 2017/2018.

Berdasarkan hasil perhitungan uji-t diperoleh $t_{\text {hitnung }}=3,870$ sedangkan pada taraf signifikansi $5 \%$ dan $\mathrm{dk}=58$ diperoleh nilai $t_{\text {tabel }}=2,000$ sehingga $t_{\text {hitnung }}=3,870>t_{\text {tabel }}=$ 2,000 . Dengan demikian, hipotesis nol (Ho yang menyatakan Tidak Terdapat pengaruh model pembelajaran Pair Check berbasis penilaian kinerja terhadap kompetensi pengetahuan PKn siswa kelas IV SDN Gugus Pattimura Denpasar Selatan tahun pelajaran 2017/2018) ditolak. Hal ini berarti terdapat pengaruh model pembelajaran Pair Check berbasis penilaian kinerja terhadap kompetensi pengetahuan PKn siswa kelas IV SDN Gugus Pattimura Denpasar Selatan tahun pelajaran 2017/2018 pada tema daerah tempat tinggalku. Perolehan hasil perhitungan analisis data yang dilakukan menunjukkan bahwa nilai rerata siswa yang mengikuti pembelajaran menggunakan model pembelajaran Pair Check berbasis penilaian kinerja $\bar{X}=84,13$ dan siswa yang mengikuti pembelajaran konvensional $\bar{X}=76,13$ memiliki perbedaan sebesar 8. Dengan demikian, terdapat pengaruh kompetensi pengetahuan PKn antara siswa kelas IV di SD Gugus Pattimura Tahun Pelajaran 2017/2018 yang mengikuti pembelajaran dengan menggunakan model pembelajaran Pair Check berbasis penilaian kinerja dan siswa yang mengikuti pembelajaran menggunakan pendekatan saintifik pada tema daerah tempat tinggalku.

Berdasarkan hasil penyetaraan, dapat dinyatakan kedua kelompok sampel penelitian yang memiliki kemampuan setara. Hasil rerata siswa kelompok eksperimen lebih tinggi dibandingkan dengan rerata siswa kontrol. Pengaruh hasil kompetensi pengetahuan dengan perolehan nilai rerata yang lebih tinggi pada kelompok eksperimen dibandingkan kelompok kontrol disebabkan oleh perlakuan berupa model pembelajaran Pair Check berbasis penilaian kinerja dalam muatan materi PKn.

Pada kelompok eksperimen, kegiatan pembelajaran dalam muatan materi PKn menggunakan model pembelajaran Pair Check berbasis penilaian kinerja berjalan dengan optimal dan kondusif. Hal ini disebabkan oleh model pembelajaran Pair Check berbasis penilaian kinerja merupakan suatu inovasi pembelajaran yang mendorong siswa untuk berpikir dan saling bekerjasama, kemudian saling bertukar peran antar anggota kelompok dan pada saat kegiatan tersebut guru dapat menilai karakteristik dari setiap peserta didik melalui penilaian kinerja siswa. Selama kegiatan pembelajaran siswa lebih aktif karena kegiatan pembelajaran menggunakan model pembelajaran Pair Check berbasis penilaian kinerja dapat menciptakan lingkungan belajar yang menyenangkan karena siswa dapat bekerja sama antar kelompok, siswa dibantu oleh rekan dalam kegiatan pembelajaran, siswa menjadi lebih sabar dan lebih memahami konsep materi pelajaran. Dengan demikian, siswa lebih memahami materi yang diberikan.

Hal tersebut di dukung oleh pernyataan dari Shoimin, (2014) yang menyatakan "kelebihan dari model pembelajaran Pair Check yakni melatih siswa untuk berusaha sendiri, melatih siswa berkomunikasi dengan teman, melatih siswa bersikap terbuka terhadap kritik dan saran yang membangun dari pasangannya, melatih siswa untu saling memberi motivasi antar pasangan". 
Hasil temuan pada penelitian ini memiliki persamaan dengan penelitian sebelumnya yang relevan dan memperkuat hasil penelitian yang diperoleh, Hal tersebut didukung hasil penelitian yang diajukan oleh Widiadnyani (2014) dengan judul "Pengaruh Model Pembelajaran Pair Cheks Berbantuan Media Lingkungan Hidup Terhadap Hasil Belajar IPA Kelas V SDN 5 Pedungan Tahun Ajaran 2013/2014" yang menyatakan bahwa terdapat perbedaan yang signifikan pada hasil belajar IPA siswa antara kelompok siswa yang dibelajarkan menggunakan model pembelajaran pair check berbantuan media lingkungan hidup dengan kelompok siswa yang dibelajarkan menggunakan model pembelajaran konvensional.

Dengan demikian, pembelajaran menggunakan model pembelajaran Pair Check berbasis penilaian kinerja pada penelitian ini memiliki keunggulan yakni dapat meningkatkan kemampuan berkerjasama dan kemampuan memberikan penilaian melalui kegiatan berpasangan dalam menyelesaikan persoalan yang diberikan melalui pengalaman belajar $5 \mathrm{M}$ didukung oleh peranan guru dalam pemberian pemantapan/pengulangan materi dan mengetahui kinerja yang dimiliki oleh setiap peserta didik melalui penilaian kinerja.

\section{Simpulan dan Saran}

Berdasarkan hasil pembahasan dan analisis dapat disimpulkan bahwa model pembelajaran Pair Check berbasis penilaian kinerja berpengaruh terhadap kompetensi pengetahuan PKn siswa kelas IV SDN Gugus Pattimura Denpasar Selatan tahun pelajaran 2017/2018. Hal ini dibuktikan dengan hasil analisis uji-t diperoleh $t_{\text {hitnung }}=3,870>t_{\text {tabel }}=$ 2,000 .

Adapun saran yang disampaikan sebagai berikut. (a) Guru diharapkan agar mencoba untuk menerapkan model pembelajaran Pair Check berbasis penilaian kinerja lebih lanjut untuk meningkatkan rasa solidaritas antar siswa, sehingga dapat meningkatkan kualitas pembelajaran sesuai dengan harapan. (b) Berdasarkan temuan penelitian, disarankan kepada kepala sekolah agar dapat menggunakan hasil penelitian ini sebagai pendukung sumber belajar guru dalam meningkatkan kualitas pembelajaran dengan menciptakan variasi pembelajaran yang menyenangkan di sekolah sehingga sekolah mampu menghasilkan siswa yang berkualitas. (c) Berdasarkan temuan penelitian, disarankan kepada peneliti agar hasil penelitian ini digunakan sebagai referensi untuk melaksanakan penelitian selanjutnya atau menemukan inovasi kegiatan pembelajaran lainnya yang bermakna dan menyenangkan bagi siswa.

\section{Daftar Pustaka}

Agung, A.A.G. 2014. Buku Ajar Metodologi Penelitian Pendidikan. Malang: Aditya Media Publishing.

Arikunto, Suharsimi. 2015. Dasar-dasar Evaluasi Pendidikan. Jakarta: Bumi Aksara.

Fathurrohman, dan Wuri Wuryandani. 2011. Pembelajaran PKn Di Sekolah Dasar. Yogyakarta: Nuha Litera.

Hamalik, Oemar. 2012. Kurikulum dan Pembelajaran. Jakarta : Bumi Aksara.

Huda, Miftahul. 2016. Model-model Pengajaran dan Pembelajaran. Yogyakarta: Pustaka Pelajar.

Kosasih, E. 2014. Strategi Belajar dan Pembelajaran Implementasi Kurikulum 2013. Bandung: Yrama Widya.

Kunandar. 2014. Penilaian Autentik.Jakarta : Raja Grafindo Persada. 
Kurniasih, Imas dan Berlin Sani. 2017. Ragam Model Pembelajaran Untuk Peningkatan Profesionalitas Guru. Jakarta : Kata Pena

Mulyasa. 2006. Kurikulum Berbasis Kompetensi. Bandung : Remaja Rosdakarya.

Sani, Ridwan Abdulah. 2016. Penilaian Autentik. Yogyakarta : Bumi Aksara.

Shoimin, Aris. 2014. Model Pembelajaran Inovatif dalam Kurikulum 2013. Yogyakarta: ARruzz Media.

Sugiyono. 2016. Metode Penelitian Kuantitatif, Kualitatif, dan R\&D. Bandung: Alfabeta.

Susanto, Ahmad. 2014. Teori Belajar dan Pembelajaran di Sekolah Dasar. Jakarta: Kencana Prenada Media Group

Widiadnyani, Luh Gd. Putri Ayu. 2014. "Pengaruh Model Pembelajaran Pair Check Berbatuan Media Lingkungan Hidup Terhadap Hasil Belajar IPA Kelas V SDN 5 Pedungan Tahun Ajaran 2013/2014". E-JournalPGSD Undiksha Mimbar PGSD Volume 2, No.1 (hlm. 1-10) (diakses pada 17 Januari 2018).

Yantiani, Ni Md. 2013. "Pembelajaran Kooperatif Pair Check Berpengaruh Terhadap Hasil Belajar Materi Bangun Ruang dan Bangun Datar Siswa Kelas IV Gugus IV Semarapura". E-Journal PGSD Undiksha Mimbar PGSD Volume 2, No.1 (hlm. 1-10) (diakses pada 17 Januari 2018). 